Seuralle ja rahastoille seuraavasti: Kotikielen Seura 3,9 \%, Sanakirjasäätiö 36,1 \%, Lauri Kettusen rahasto 31,8 \%, E. A. Saarimaan rahasto $26,6 \%$ ja Hesteon koululaiskielirahasto 1,6\%. Seuran ja Virittään pankkitalletusten kokonaismäärä on ollut tilikauden päättyessä 32 657,34 euroa, joista Virittäjän osuus on ollut 19 371,66 euroa. Vuoden 2017 taseessa vastaavaa ja vastattavaa on kumpaakin 215 914,71 euroa.

Virittäjän tuotot olivat vuonna 2017 ilman avustuksia yhteensä 31 o89,98 euroa. Nämä tuotot ovat kertyneet tilausmaksuista (30 886,59 euroa) ja korkotuotoista (203,39 euroa). Tieteellisten Seurain Valtuuskunnan myöntämä julkaisuavustus oli 19 ooo euroa. Näiden lisäksi oli muita tuottoja 4 842,26 euroa. Yhteensä Virittäjän tuotot olivat 54 932,24 euroa. Menoja kertyi 54 932,24 euroa. Suurimmat kulut aiheutuivat painatuksesta ja postituksesta (18 921,73 euroa) sekä henkilöstökuluista (27 684,83 euroa). Virittäjän tulos vuodelta 2017 osoittaa nollaa. Taseeseen on merkitty vuoden 2017 julkaisuavustuksen palautusta 3 368,22 euroa.

Seuran tuotot koostuivat pääosin jäsenmaksuista, jotka olivat 2 616,0o euroa. Seuran varsinaisen toiminnan kulut olivat 3 540,27 euroa, ja ne koostuivat pääosin jäsenkokousten järjestämisestä ja kirjanpidosta. Sijoitus- ja rahoitustoiminnan tulos oli 10 814,38 euroa, ja rahastoihin tuotoista siirrettiin 10 614,39 euroa. Seuran tulos vuodelta 2017 on 724,28 euroa alijäämäinen.

Kotikielen Seuran ja Virittäjän vuoden 2017 yhteinen tilinpäätös osoittaa tuottoja 68 619,15 euroa, kuluja 58 729,04 euroa ja rahastoille siirrettävää tuottoa 10 614,39 euroa. Alijäämäksi muodostuu 724,28 euroa.

Helsingissä 27. helmikuuta 2018

Pilvi Heinonen seura@kotikielenseura.fi Kotikielen Seuran sihteeri

\title{
Megatrendi: julkisten hyvinvointialojen tekstualisoituminen
}

Ulla Tiililä \& Kati Karvinen (toim.): Elämän ja kuoleman tekstit. Kirjoittaminen sosiaali-ja hoitotyössä. Helsinki: Kotimaisten kielten keskus 2017. 203 s. ISBN 978-952-5446-90-6. Kirja on luettavissa osoitteessa http://scripta.kotus.fi/www/ verkkojulkaisut/julk50/Elaman_ja_kuoleman_tekstit.pdf.
Ulla Tiililän ja Kati Karvisen toimittama Elämän ja kuoleman tekstit: Kirjoittaminen sosiaali- ja hoitotyössä tarkastelee aikamme todellista megatrendiä: yhä enemmän tekstityöksi muuttunutta sosiaali- ja hoitotyötä. Teos juontaa juurensa Kotimaisten kielten keskuksessa vuonna 2006 alkaneeseen Ulla Tiililän johtamaan 
Tekstualisoituva julkishallinto -hankkeeseen. Hankkeessa syntyi kaikkiaan 13 opinnäytetyötä, joihin suuri osa teoksen artikkeleista perustuu. Opinnäytteistä yhdeksän on suomen kielen pro gradu -töitä; lisäksi mukana on kaksi kandidaatintyötä sekä kaksi opinnäytettä sosiologiasta.

Kirjan keskeinen pyrkimys on kuvata ja havainnollistaa sitä, millä tavoin kieli kytkeytyy sosiaali- ja hoitotyössä aina "muuhun työhön" ja miten muu työ on elimellisesti myös tekstityötä. Artikkeleissa valotetaan erilaisen kirjoittamisen, kirjaamisen ja dokumentoinnin tavoitteita ja vaikutuksia sekä tuodaan havainnollisesti esiin lainsäädännön, tietojärjestelmien, toiminnan ja kielen suhteita. Tältä osin kirja edustaakin uudenlaista lähestymistapaa virkatekstien tutkimiseen: tekstejä tarkastellaan ottamalla huomioon se, missä, miksi, kenelle ja miten tekstejä tuotetaan. Hankkeen tuloksia on esitelty aiemmin muun muassa Kielikellossa (esim. Lehtinen 2008; Karvinen 2009; Pyhäniemi 2010) sekä Kieli työssä -artikkelikokoelmassa (Tiililä 2011).

Tiililän mukaan (s. 9) hyvinvointialojen kielenkäyttöä on tutkittu Suomessa kielitieteellisesti vain vähän, osittain siitä syystä, että tutkijan on vaikea saada sopivaa aineistoa käsiinsä sen arkaluonteisuuden vuoksi. Lisäksi se, että monet sosiaali- ja hoitotyön tekstit edellyttävät syvällistä perehtymistä myös tekstien konteksteihin, voi johtaa siihen, etteivät tekstit ole päätyneet useammin tutkimuksen kohteiksi. Tiililä on itse uranuurtaja sosiaali- ja hoiva-alojen kielenkäytön tutkijana Suomessa (ks. esim. Tiililä 2007).

\section{Kokoelman rakenne}

Tekstualisoituva julkishallinto -hankkeessa tekstien tarkastelu keskitettiin kolmelle alalle: lasten päivähoitoon, toimeentulotuen sosiaalityöhön sekä kotihoitoon. Näihin liittyviä tekstejä käsitellään myös kokoelman artikkeleissa, jotka tuo- vat monipuolisesti esiin hallinnon tekstejä ihmisen elämänkaaren eri vaiheista. Kirjan ensimmäisessä osassa tarkastellaan kirjoittamisen puitteita ja vaikutuksia esimerkiksi päivähoidossa, mielenterveystyössä ja lastensuojelussa. Näkökulma ei ole teksteissä vaan siinä, millaiset asiat vaikuttavat kirjoittamiseen ja ohjaavat kirjoittamista työssä. Ensimmäisessä osassa esimerkiksi havainnollistetaan konkreettisesti sitä, miten tekniikan kehittyminen on muuttanut kirjoittamista sosiaalivirastossa ja miten työntekijät ovat suhtautuneet tietokoneiden tuomaan muutokseen.

Kokoelman toisessa osassa keskitytään päivähoidon tekstimaailmaan, ja nyt tutkimuksen kohteena on nimenomaan kieli. Tarkasteltavana on esimerkiksi se, miten viraston toimintakertomukset ovat muuttuneet vuosikymmenten saatossa sekä millaisilla sanoilla ja syntaktisilla rakenteilla huoltajia ohjaillaan varhaiskasvatusviraston lähettämissä tiedotteissa.

Kolmannessa osassa käsitellään tekstejä sosiaalityössä, ja näkökulma on niin tekstien tuottamisen prosesseissa kuin tekstien kielellisissä rakenteissakin. Osa alkaa Helsingin kaupungin aikuissosiaalityön päällikön Anne Qvistin artikkelilla "Kuinka toimeentulotukipäätös syntyy Helsingin sosiaali- ja terveysvirastossa?". Qvistin artikkeli tuo ainakin kielentutkijalle uutta ja kiinnostavaa tietoa tekstin tuottamisen prosesseista virastomaailmassa.

Neljännessä osassa tutkitaan kotihoidon tekstejä, esimerkiksi sitä, miten kirjaaminen liittyy osaksi hoitajan työtä, millaiset säädökset ja lait ohjaavat kirjaamista sekä millaisia vaatimuksia kirjaamiseen liittyy. Lisäksi tarkastellaan hoitokertomusten kieltä: sananvalintoja, sävyä ja lyhenteitä.

Kokoelma päättyy Jenni Viinikan artikkeliin "Elämän esirippu sulkeutuu: Kuolintodistusten performatiivisuus", jossa tarkastellaan kuolintodistusten kieltä. Artikkeli osoittaa sanan mahdin ja dokument- 
tien voiman: ihmisen virallinen olemassaolo ei päätykään fysiologiseen kuolemaan vaan institutionaaliseen kielenkäyttöön, kuolintodistukseen.

\section{Elämän ja kuoleman tekstit kirjoittamisen opetuksen tukena}

Opetan ammattikorkeakoulussa sosiaalialan opiskelijoille suomen kieltä ja viestintää, ja yhtenä haasteena työssäni on aina ollut se, että autenttisia sosiaalialan tekstejä on ollut vaikea saada tarkastelun kohteeksi. Kuitenkin juuri aitojen työelämän tekstien tarkastelu motivoisi opiskelijoita kaikkein parhaiten. Tästä näkökulmasta Tiililän ja Karvisen toimittama kokoelma on todella tervetullutta opetusmateriaalia. Teoksessa sosiaalialan tekstityötä avataan aitojen tekstiesimerkkien kautta toisaalta kielen ammattilaisen, toisaalta sosiaalialan ammattilaisen näkökulmasta. Julkishallinnon tekstejä ei tarkastella irrallaan ympäröivästä todellisuudesta. Tärkeitä ovat havainnot siitä, miten hankalankin kielellisen rakenteen käyttö saattaa olla ammattilaisen näkökulmasta perusteltua. Kirjan tarkoituksena ei ole kritisoida viranomaisen kielivalintoja vaan tarkastella sitä, mitä erilaisista valinnoista seuraa.

Omassa kirjoituksen opetuksessani tuntuu korostuvan se, että onnistunut teksti ja hyvät kielelliset valinnat ovat yksittäisen kielenkäyttäjän varassa. Opiskelumaailmassa näin onkin: opiskelijoilla on aikaa muokata tekstejään ja pohtia sitä, mitä on selkeä ja ymmärrettävä kieli. Työelämässä kirjoittajan todellisuus on toinen. Sosiaalialalla kirjoittamista säätelevät muun muassa lainsäädäntö, työpaikan omat ohjeistukset, valtava aikapula sekä monesti myös lomakkeiden määrämuotoiset rakenteet. Työelämän todellisuudessa esimerkiksi kiilalause tai pilkun paikka saattavat tuntua toissijaisilta, oikeastaan kokonaan toiseen maailmaan kuuluvilta ilmiöiltä.
Elämän ja kuoleman tekstit avaa havainnollisesti viranomaistekstien tuottamisen prosessia. Näkemykseni mukaan yksi teoksen keskeisimmistä hyödyistä opetukselle onkin juuri se, että tämä viranomaisen kirjoitusprosessi tehdään näkyväksi. Artikkeleissa kuvataan sitä, millaisissa tilanteissa ja millaisten vaatimusten paineessa työelämän tekstejä, esimerkiksi toiminta- ja hoitokertomuksia sekä toimeentulotukipäätöksiä, tuotetaan. Kokoelma myös havainnollistaa, miten asiakirjat voivat parhaimmillaan auttaa parhaan mahdollisen hoidon järjestämisessä ja suunnittelussa. Pahimmillaan asiakirjoilla vain pönkitetään organisaation asemaa ja hallintologiikkaa. Mielestäni on tärkeää, että opiskelijat voivat jo opintojensa aikana pohtia tekstien tuottamisen lähtökohtia: Kenen näkökulmasta asiat on kerrottava? Ketä varten dokumentteja tehdään? Mitä tarkoitusta ne ensisijaisesti palvelevat?

Elämän ja kuoleman tekstit osoittaa, että asiakirjojen tarkoituksenmukainen hyödyntäminen sosiaali- ja hoitotyössä vaatii hyvän kielitaidon ja tilannetajun lisäksi uskallusta soveltaa ohjeita ja säädöksiä tilanteen mukaan ja rohkeutta tehdä yksilöllisiä ratkaisuja. Tällaista maalaisjärjen käyttöä voi kokemukseni mukaan opettaa parhaiten juuri avaamalla asiakirjojen synnyttämää toimintalogiikkaa ja niihin liittyviä haasteita - esimerkiksi tämän artikkelikokoelman avulla.

\section{Lait tekstityön lisääntymisen taustalla}

Erityisen ajankohtaisen arvioitavasta teoksesta tekee se, että laki sosiaalihuollon asiakasasiakirjoista (2015/254) tuli voimaan 1.4.2015. Laki tuo yleisen kirjaamisvelvoitteen sosiaalihuoltoon ja vaikuttaa siten jokaisen sosiaalihuollon asiakastietoja käsittelevän henkilön työhön. Lisäksi lain avulla sosiaalialan kirjavia dokumentointikäytäntöjä pyritään 
yhdenmukaistamaan. Hoitoalalla kirjaamisen käytäntöihin vaikuttaa potilastiedon arkiston, Kanta-palvelun, laajeneminen koko Suomea koskevaksi. Tavoitteena on, että palvelu ulottuisi lähivuosina koskemaan kaikkia niitä, jotka käyttävät sosiaali- ja terveydenhuollon palveluja, jotta tiedonvaihto eri asiantuntijoiden välillä paranisi. Samalla valtakunnallinen arkisto pyrkii lisäämään ymmärrettävän, asiallisen ja selkeän kirjaamisen merkitystä. Kun asiakkaalla on mahdollisuus tarkastella omia asiakastietojaan vaikka kotikoneeltaan, nousee myös ymmärrettävän ja asiakasta kunnioittavan kirjaamisen merkitys esiin entistä selvemmin.

Lastensuojelutyöhön liittyvä resurssipula on ollut paljon esillä julkisuuteen tulleiden perhetragedioiden vuoksi. Resurssipulaa ei ainakaan helpota se, että uuden lastensuojelulain (2007/417) myötä työntekijöitä velvoitetaan tuottamaan yhä enemmän erilaisia dokumentteja asiakkaistaan. Kokoelmassa aihepiiriä käsitellään Raija Koskisen artikkelissa "Lastensuojelun sosiaalityö ja asiakastietojärjestelmä muutoksessa". Koskinen tuo esiin, että ajantasaiseen kirjaamiseen ei ole läheskään aina mahdollisuuksia. Lisäksi Koskinen kuvaa havainnollisesti asiakastietojärjestelmän mukanaan tuomia haasteita. Järjestelmää kehitettäessä on pyritty ottamaan huomioon lastensuojelulain ja muun lainsäädännön vaatimukset sekä kaupungin organisaation omat toimintatavat. Tällainen räätälöinti on kuitenkin johtanut siihen, että kaikki työvaiheet pitää tehdä sovellukseen oikeassa järjestyksessä. Esimerkiksi lastensuojelun piirissä olevan monilapsisen perheen jokaisesta lapsesta on luotava tietojärjestelmään oma "asiakkuus" ja kirjattava samat vaiheet moneen kertaan - jokaisen kohdalla erikseen. Yksittäinen puutteellinen kirjaus tai se, ettei asiakkaan asiakirjoja ole liitetty toisiinsa oikein, saattaa estää asian hoitamisen. Järjestelmien kehittäjiä onkin syytetty käytännön laiminlyön- nistä: järjestelmissä ei oteta kylliksi huomioon niitä olosuhteita, jotka vaikuttavat toiminnan sujuvuuteen (s. 54; ks. myös Heath \& Luff 2000: 57, 249-250).

Koskisen artikkelia lukiessa mieleeni tuli myös äskettäin julkaistu Tarja Vierulan (2017) väitöstutkimus, joka käsittelee lastensuojelun asiakkaina olevien lasten vanhempien näkemyksiä itseään koskevista lastensuojelun asiakirjoista. Vierula tuo esiin asiakkaiden näkökulman dokumentaatioon: Vanhemmat eivät juuri voi vaikuttaa siihen, millaisia asioita heidän elämästään kirjoitetaan lastensuojelun asiakirjoihin. He eivät myöskään voi määritellä sitä, kuka asiakirjoja lukee, miten niitä tulkitaan ja mitä tarkoitusta varten. Koska asiakirjat ja niiden sisällöt ovat pysyviä, niitä voidaan lukea ja tulkita vuosikymmentenkin päästä muuttumattomina kuvauksina vanhempien ja lasten henkilökohtaisesta elämästä. Tällaisia tutkimustuloksia vasten lastensuojelun dokumentointikäytäntöjen tutkiminen tuntuu erityisen tarpeelliselta. Koskisen artikkeli tekeekin ansiokkaasti näkyväksi uuteen lastensuojelulakiin liittyviä puutteita ja herättelee pohtimaan sellaisten päätösten tarkoituksenmukaisuutta, joiden toimeenpanoon ei järjestetä kylliksi resursseja.

\section{Vakiotekstien ja vapaasti kirjoitettujen osien palapeli}

Anne Qvistin artikkelissa "Kuinka toimeentulotukipäätös syntyy Helsingin sosiaali- ja terveysvirastossa?" avataan havainnollisesti sitä, millaiselta toimeentulotukipäätöksen tuottamisprosessi näytti päätöksentekijän ja tietojärjestelmän näkökulmasta vuonna 2012. Qvist tuo esiin niitä teknisiä haasteita, joita päätöksen kirjoittamiseen liittyy. Esimerkiksi se, että asiakastietojärjestelmässä ei ole esikatselutoimintoa tai että tietoja on vaikea muuttaa tai korjata jälkeenpäin, tekevät koherentin tekstin tuottamisesta vaikeaa. Tuntuu eri- 
koiselta, että haasteet voivat olla tällä tasolla vielä 2010-luvulla. Artikkelin luettuani jäin pohtimaan, mitähän toimeentulotukipäätöksille kuuluu nykyään, kun kaikki perustoimeentulotukiasiat siirtyivät vuoden 2017 alusta Kelan hoitoon. Jatkossa olisi tärkeää selvittää myös sitä, näyttäytyvätkö päätökset asiakkaille nyt selkeämpinä kuin ennen (vrt. Laaksonen 2011).

Qvistin artikkelista käy hyvin ilmi, että päätöstekstit rakennetaan vakiotekstien ja vapaasti kirjoitettujen tekstien palapelinä. Sosiaalialan kirjoittamisen opetuksessa olisikin kiinnitettävä huomiota juuri tämän tyyppisten tekstien tuottamisen haasteisiin. Opiskelijoille olisi annettava eväitä siihen, miten päätöksentekijä voi pienillä kielellisillä keinoilla luoda päätöstekstiin koherenssia tilanteessa, jossa päätöksentekijän oman muotoilun rinnalla mukana on myös jäykkiä, vakiomuotoisia tekstin osia.

\section{Vinkkejä kirjoittamiseen ja S2-opetukseen}

Kati Karvinen, Taina Lehtomäki ja AnnaLeea Honkala osoittavat kotihoidon kirjaamista koskevissa artikkeleissaan, millaiset kielelliset valinnat parantavat tekstin ymmärrettävyyttä ja tukevat vuorovaikutusta, millaiset taas haittaavat ymmärtämistä. Karvisen artikkelissa "Asiakas ja hoitaja kotihoidon hoitokertomuksissa" tarkastelun kohteena ovat tavat, joilla hoitokertomuksissa viitataan asiakkaaseen. Hänen mukaansa asiakkaaseen ei aina viitata näkyvästi (esim. iltapesut ja yöasun vaihto) ja tyypillistä on passiivin (esim. annettu, otetaan) ja verbin nominaalistusten (esim. rasvaus, hiusten laitto) käyttö. Kirjauksissa nominaalistuksilla ja passiivilla on omat tehtävänsä. Nominaalistuksilla kuvataan ongelmattomia rutiinikäyntejä, ja ne yhtenäistävät ja helpottavat kirjaamista. Passiivin avulla taas voidaan rakentaa ammatillista uskottavuutta ja keventää henkilökohtaista vas- tuuta työssä, jota tehdään monen eri toimijan voimin (silmätipat laitettu, tukisukat laitettu). Lehtomäki puolestaan tarkastelee artikkelissaan "Lyhenteet kotihoidon hoitokertomuksissa" sitä, millaisia lyhenteitä hoitokertomuksissa esiintyy ja kuinka ymmärrettäviä ne ovat. Suurin osa lyhenteistä on (ennakko-oletusten vastaisesti) pääteltävissä kontekstista. Hankalia ovat kuitenkin esimerkiksi verbilyhenteet, joista ei käy ilmi, mikä verbinmuoto on kyseessä (esim. ilm. potilaalle 'ilmoitetaan potilaalle' vs. 'ilmoitettu potilaalle'). Myös lyhenneketjuista saattaa olla vaikea hahmottaa osien rajoja (esim. Infl.rokote im.l.sin. RR 143/85,p.79). Kiinnostava on myös Lehtomäen havainto siitä, että sairaanhoitajat käyttävät lyhenteitä enemmän kuin lähihoitajat. Parhaimmillaan lyhenteet tuovat tekstiin täsmällisyyttä ja nopeuttavat lukemista, pahimmillaan ne hankaloittavat ymmärtämistä.

Honkalan artikkelissa "Kotihoidon ongelmatilanteiden kirjaamisesta" taas tuodaan esiin, kuinka ongelmatilanteita kuvataan hoitokertomuksissa usein monisanaisesti ja yksityiskohtaisesti: mukana on asiakkaan puheen referointia (esim. "Kyllästyttää, kylläinen olo ja on muutenkin kurja olo" on vastaus...), ja monesti ongelmatilanteissa on myös partikkeli kuulemma osoittamassa eroa oman kokemuksen ja asiakkaan kertoman välillä. Asiakkaan ja oman toiminnan yksityiskohtaisen kuvaamisen taustalla näyttää usein olevan kirjaajan tarve osoittaa, että hän on haastavassakin tilanteessa toiminut ohjeiden ja säännösten mukaisesti.

Ammattiliitto Tehyn selvityksen mukaan maahanmuuttajataustaisten hoitajien suurimpia haasteita työssä ovat kirjoitustaito ja kirjaaminen (Koivuniemi 2012: 26-27). Koska tulevaisuudessa yhä useampi maahanmuuttaja sijoittuu hoitoalalle, tarvitaan työelämälähtöistä, räätälöityä kielikoulutusta. Kokoelman kotihoidon kirjauksia käsittelevistä artikke- 
leista saakin hyödyllisiä vinkkejä ja havainnollista materiaalia hoitajille räätälöityyn S2-opetukseen. Erityisen tärkeää on tunnistaa kielen sävyjä ja merkitysvivahteita. Karvisen ja Honkalan mukaan odotuksenvastaisista tai ongelmallisista kotikäynneistä tehdyt kirjausmerkinnät ovat tyypillisesti yksityiskohtaisia ja kuvailevia. Jos kotihoitaja kirjaa ongelmallisen käynnin lakonisesti, vakiomuotoisia fraaseja käyttäen, ei potilaan hoidon kannalta merkityksellinen tieto hoitotilanteen haasteellisuudesta välttämättä välity seuraavalle hoitajalle. Myös asiakkaan ääni voidaan nostaa kirjauksessa esiin silloin, kun tilanteen haastavuutta halutaan tuoda esille neutraalisti. Näin tapahtuu esimerkiksi seuraavassa: kertoo voivansa huonosti, vaikka kävelee

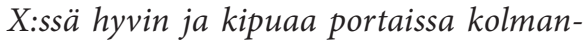
teen kerrokseen puuskuttamatta. Tämä voi auttaa kokematonta hoitajaa ymmärtämään toisten tekemiä kirjauksia kokonaisvaltaisemmin sekä kirjaamaan itse ongelmatilanteita neutraalisti ja potilasta kunnioittaen.

Vaikka kieleen liittyvät tutkimustulokset ovat aina ajankohtaisia, arvioitavaa kokoelmaa lukiessa huomaa väistämättä sen, miten nopeasti kirjoittamisprosessiin liittyvät asiat muuttuvat etenkin sosiaalialalla. Esimerkiksi Annika Pihlajamäen artikkelissa "Vanhempien ohjailu päivähoidon tiedotteissa" käytetään vielä vanhaa nimitystä päivähoito, vaikka nykyään puhutaan varhaiskasvatuksesta. Pihlajamäen aineisto koostuu vuosina 2007-2008 poimituista Helsingin kaupungin internetsivuilla julkaistuista tiedotteista ja ohjeista. Artikkelissa osoitetaan vakuuttavasti, miten virkakielen yhteydessä paljon parjatulla passiivillakin on oma tehtävänsä. Ohjeistuksessa passiivilla tai nollapersoonalla voidaan ottaa huomioon erilaiset perhetilanteet jättämällä taustalle se, kuka lapsen tuo hoitoon tai hakee hoidosta (esim. Lapset, jotka eivät jää yöhoitoon, haetaan pääsääntöisesti 21 mennessä... Sairasta lasta ei voi tuoda päivähoitoon).

Uusi varhaiskasvatuslaki (2015/580) lisää omalta osaltaan kirjoittamisen määrää, sillä laki velvoittaa varhaiskasvattajia tekemään jokaisesta lapsesta varhaiskasvatussuunnitelman, johon listataan lapsen oppimistavoitteet ja ne toimenpiteet, joiden avulla tavoitteisiin päästään. Myös lapsen huoltajien rooli tuodaan uudessa laissa vahvemmin esiin, sillä lapsen yksilöllisiä tavoitteita on tarkoitus pohtia yhdessä huoltajien kanssa. Olisi ollut kiinnostavaa nähdä, näkyykö tämä vahvempi rooli myös tiedotteissa ja vanhempien ohjailussa.

\section{Deskriptiivinen näkökulma kieleen}

Artikkeleiden lomassa on yhdeksän tietolaatikkoa, joissa tekstien kielellisiä piirteitä kuvaavia käsitteitä, kuten lauseketta, tekstin abstraktisuutta, semanttisia rooleja tai affektiivisuutta, avataan lyhyesti maallikolle. Esimerkiksi passiivitietolaatikossa (s. 102) tuodaan esiin, että passiivia käyttämällä puhuja voi tehdä väitteestään yleispätevän, suojella toimintaan osallistuvien kasvoja tai välttää oman toimintansa korostamista. Lauseketietolaatikossa (s. 84) taas havainnollistetaan sitä, miten pitkän lausekkeen korvaaminen pronominilla tekee tekstistä sidosteista. Vakiokatkelmista koostetuissa teksteissä lausekkeita ei kuitenkaan yleensä voi korvata pronomineilla, mikä johtaa pitkien lausekkeiden toistoon, joskus jopa peräkkäisissä virkkeissä. Tietolaatikoista on kirjoittamisen opetuksessa paljon apua, sillä ne havainnollistavat ja monipuolistavat kuvaa siitä, millaiset rakenteet toimivat hyvin ja mitä taas olisi syytä välttää. Elämän ja kuoleman tekstit ei kuitenkaan anna listaa "kielletyistä" sanoista tai kapulakielisistä rakenteista. Kielen rakenteita lähestytään pikemminkin deskriptiivisesti, kuvailevasti. Opettajana olisin kaivannut joitakin norma- 
tiivisia avauksia, vaikkapa vain varovaisia ohjeita tai vinkkejä niille viranomaisille, jotka tuottavat tekstejä monenlaisen paineen alla, erilaisia valintoja tehden. Erityisen paljon kaipasin konkreettisia vinkkejä lukiessani Ulla Tiililän ja Emilia Laurilan artikkelia "Perusteleminen toimeentulotukipäätöksissä". Artikkelissa pohditaan ansiokkaasti toimeentulotukipäätösten perustelujaksoja ja tuodaan esiin päätöstekstien monitehtäväisyys ja moniäänisyys. Päätöstekstin sisällä voi kuulua lääkärin, ulosottoviranomaisen, asiakkaan sekä päätöksentekijän ääni. Tästä moniäänisyydestä syntyy tekstin haasteellisuus, ja toisinaan päätöksen perusteluiden ymmärtäminen saattaa vaatia asiakkaalta päättelykykyä ja lakitekstin tuntemista. Tiililä ja Laurila päättävät artikkelinsa yhteenvetoon siitä, mitkä ovat hyvien perusteluiden tuntomerkkejä: lukija löytää perustelun tekstistä helposti, hänen ei tarvitse päätellä perustelun sisältöä vihjeiden tai lisälukemisen avulla ja perustelut pohjautuvat oikein tulkittuihin ja huolellisesti toistettuihin tosiseikkoihin. Opettajan näkökulmasta tähän loppuun olisi sopinut tekstiesimerkkipari, jossa alkuperäisen päätöstekstin epäselviä perusteluita olisi muokattu lukijalle läpinäkyvämmiksi. Yksi konkreettinen esimerkki havainnollistaisi ilmiötä tekstintutkimusta tuntemattomalle paremmin kuin erilaisten perusteluiden kielellinen analyysi - vaikka analyysi toimiikin kaiken lähtökohtana. Toisaalta kirjassa osoitetaan, kuinka erilaiset vaatimukset, funktiot, ohjeet, aikarajoitukset, tekniset rajoitukset ja lait ohjaavat tekstien tuottamista niin, että yleispätevien kirjoitusohjeiden antaminen on vaikeaa.

\section{Työelämän todellisuus näkyviin opetuksessa}

Artikkelikokoelma on tervetullut lukupaketti kaikille työelämän viestinnästä ja sosiaali- ja hoitoalan teksteistä kiinnostu- neille. Vaikka kokoelmassa on kielitieteellinen ote, teksti on yleistajuista ja lähestyy kielen piirteitä ilmiöiden kautta. Niinpä teksti avautuu helposti myös kielitiedettä tuntemattomille. Toivon, että teos löytää tiensä erityisesti sosiaali- ja hoitoalan opiskelijoiden kurssikirjalistoille. Positiivista on, että kokoelma on saatavilla avoimesti verkossa.

Kokoelman luettuani minulle heräsi kiinnostus tuoda opetuksessa vahvemmin esiin sosiaalialan ammattihenkilön kokemusta työelämän todellisuudesta: sitä, millaisissa tilanteissa ja millaisten ristiriitaisten vaatimusten paineessa sosiaalialan tekstejä tuotetaan. Joudun työssäni myös lähes viikoittain perustelemaan opiskelijoille, miksi vaadimme niin valintakokeessa kuin opinnoissakin hyvää suomen kielen taitoa. Jotkut pitävät vaatimuksia eriarvoistavina, jopa $\mathrm{S}_{2}-$ opiskelijoita syrjivinä. Elämän ja kuoleman tekstit osoittaa, että keskeinen osa sosiaalialan työntekijän ammattitaitoa on hyvän tekstin tuottaminen, kielen sävyjen tunnistaminen sekä monimutkaisten virkakielisten rakenteiden ymmärtäminen ja tulkitseminen. Jokaisella sosiaalihuollon asiakkaalla pitäisi olla oikeus siihen, että hänen asioitaan hoitaa viranomainen, jolla on hyvä suomen kielen taito.

\section{EveliInA Korpela etunimi.sukunimi@metropolia.fi}

Kirjoittaja on suomen kielen tohtori ja toimii suomen kielen ja viestinnän lehtorina Metropolia-ammattikorkeakoulussa.

\section{Lähteet}
Heath, Christian - Luff, Paul 2000: Technology in action. Cambridge: Cam- bridge University Press.
KARVinen, KATi 2009: Kotihoidon teksteillä monta tehtävää. - Kielikello 1/2009.
KoIvuniemi, SARI 2012: Maahanmuuttaja-


taustainen koulutettu hoitohenkilökunta sosiaali- ja terveydenhuollon työyhteisöissä. Tehyn julkaisusarja B: 1/12 selvityksiä. Helsinki: Tehy.

LAAKSONEN, KAINO 2011: Ymmärrettävämpiä tekstejä Kelasta. - Kielikello 4/2011.

Laki lasten päivähoidosta annetun lain muuttamisesta 2015/580. https://www.finlex.fi/ fi/laki/alkup/2015/2015058o (28.5.2018).

Laki sosiaalihuollon asiakasasiakirjoista 2015/254. https://www.finlex.fi/fi/laki/ alkup/2015/20150254 (28.5.2018).

Lastensuojelulaki 2007/417. https://www. finlex.fi/fi/laki/alkup/2007/20070417 (28.5.2018).

Lehtinen, Essi 2008: Kertomuksia lapsista ja lasten määristä - Virastojen toimintakertomusten muutoksia.
- Kielikello 4/2008.

Рyнäniemi, SaIja 2010: Päiväkotien kirjoitustyöt: mitä, miten, milloin?

- Kielikello 1/2010.

Tillilä, Ulla 2007: Tekstit viraston työssä. Tutkimus etuuspäätösten kielestä ja konteksteista. Helsinki: Suomalaisen Kirjallisuuden Seura. 2011: Sanoilla lavastettu virasto. Tietoyhteiskunnan arkea sosiaali- ja hoivaaloilla. - Marjut Johansson, Pirkko Nuolijärvi \& Riitta Pyykkö (toim.), Kieli työssä. Asiantuntijatyön kielelliset käytännöt s. 162-189. Helsinki: Suomalaisen Kirjallisuuden Seura.

Vierula, TARJA 2017: Lastensuojelun asiakirjat vanhempien näkökulmasta. Tampere: Tampereen yliopisto. http:// urn.fi/URN:ISBN:978-952-03-0565-9.

\section{Suomenruotsin murteista, vaihtelusta ja muuttuvasta kielimaisemasta}

Ann-Marie Ivars: Dialekter och småstadsspråk. Svenskan i Finland - i dag och i går I:1. Skrifter utgivna av Svenska litteratursällskapet i Finland 798. Helsingfors:

Svenska litteratursällskapet i Finland 2015. 464 s. ISBN 978-951-583-336-5.

Marika Tandefelt (toim.): Gruppspråk, samspråk, två språk. Svenskan i Finland - i dag och i går l:2. Skrifter utgivna av Svenska litteratursällskapet i Finland 799. Helsingfors: Svenska litteratursällskapet i Finland 2015. 252 s. ISBN 978-951-583-337-2.

Tässä kirjoituksessa arvioitavat teokset ovat kaksi ensimmäistä kuusiosaisesta kirjasarjasta Svenskan i Finland - i dag och i går. Sarjan neljä ensimmäistä osaa on jo julkaistu (ks. myös Hiidenmaa tässä numerossa), kaksi osaa on suunniteltu julkaistavaksi vuonna 2019. Kirjasarja on tulosta samannimisestä hankkeesta (20102017), jonka suurin rahoittaja on Svenska litteratursällskapet i Finland (SLS). Projektin tavoitteena on esittää kattava kuvaus suomenruotsista sen erilaisissa puhutuissa ja kirjoitetuissa muodoissa sekä tuoda esiin niitä ominaisuuksia, joita suomenruotsilla on niin kutsuttuna monikeskuksisena kielenä (samaa kieltä puhutaan kahdessa tai useammassa maassa jossain määrin omina standardoituina varieteetteinaan). Tarkoituksena ei ole kuvata vain nykyistä suomenruotsia vaan muodostaa käsitys myös siitä, miten suomenruotsi on muuttunut aikojen kuluessa. 